\title{
Electrochemical Determination of Metallothioneins by the Modified Brdička Procedure as an Analytical Tool in Biomonitoring Studies
}

\author{
Tatjana Mijošek,* Marijana Erk, Vlatka Filipović Marijić, Nesrete Krasnići, Zrinka Dragun, Dušica Ivanković
}

Ruđer Bošković Institute, Division for Marine and Environmental Research, Bijenička cesta 54, HR-10000 Zagreb, Croatia
${ }^{*}$ Corresponding author's e-mail address: tmijosek@irb.hr

RECEIVED: October 31, 2018 * REVISED: January 25, 2019 * ACCEPTED: January 28, 2019

PROCEEDING OF THE $5^{\text {Th }}$ DAY OF Electrochemistry AND $8^{\text {TH }}$ ISE SSRSE, 25 MAY 2018, ZAGREB, CROATIA

\begin{abstract}
Present study aims to improve the modified Brdička procedure of metallothionein (MT) quantification in a way to reduce the analysis duration. Therefore, scan rate of the voltammetric sweep was increased from $0.0052 \mathrm{~V} \mathrm{~s}^{-1}$ to $0.013 \mathrm{~V} \mathrm{~s}^{-1}$ by lowering the duration of one step potential from $0.5 \mathrm{~s}$ to $0.2 \mathrm{~s}$, which resulted in 2.5 times faster voltammetric sweep. Research confirmed high accuracy and reliability of MT measurements, in both standard sample and samples of heat-treated cytosols of liver, gills and the intestine of European chub and liver of brown trout. The method was confirmed as fast and reliable electrochemical technique for quantification of MTs and this time-saving improvement is especially useful and applicable in different biomonitoring studies which require the analyses of numerous biological samples and high sample throughput.
\end{abstract}

Keywords: metallothioneins, differential pulse voltammetry, modified scan rate, fish tissues, biomarkers, biomonitoring.

\section{INTRODUCTION}

$\mathbf{M}$ ETALLOTHIONEINS (MTs) are the family of inducible metal-binding proteins which have important roles in the homeostasis of essential trace metals ( $\mathrm{Cu}$ and $\mathrm{Zn}$ ) and/or sequestration of toxic metals (e.g., $\mathrm{Ag}, \mathrm{Cd}$ and $\mathrm{Hg}$ ), as well as in the protection against oxidative damage. ${ }^{[1,2]}$ They are characterized by low molecular mass, lack of aromatic amino acids and high cysteine content. Increased MTs reduce toxic effects caused by metals and at cellular level are one of the first detectable signs of the occurrence of elevated metal levels. Therefore, MTs are often used in biomonitoring studies as biomarkers of metal exposure. ${ }^{[2,3]}$ Analytical methods used for MT determination cover a broad range of techniques including direct detection of MTs (immunochemistry, mass spectrometry and electrochemistry) and indirect detection of MTs (saturation assays with $\mathrm{Hg}, \mathrm{Cd}$ or $\mathrm{Ag}$, and spectrometric methods via metal detection in proteomics). ${ }^{[4,5]} \mathrm{A}$ method for polarographic determination of proteins containing thiol groups in ammonia buffered cobalt(III) solution was first introduced by
Brdička. ${ }^{[6]}$ Since then, the procedure has been modified by Paleček and Pechan, ${ }^{[7]} \mathrm{Kehr},{ }^{[8]}$ Olafson and Sim, ${ }^{[9]}$ Thompson and Cosson, ${ }^{[10]}$ and Olsson and Haux. ${ }^{[11]}$ Therefore, the method used today is commonly known as modified Brdička reaction. Main improvements from the original procedure include application of pulse techniques and hanging mercury electrode instead of the dropping one, ${ }^{[9]}$ which resulted in better resolution and more reliable quantification. The exact mechanism of the reaction was elucidated by Raspor. ${ }^{[12]}$ Quantification of MTs in the reaction is based on linear relationship between the catalytic hydrogen evolution signal and protein concentration. ${ }^{[12]}$ Besides, it was discovered that the height of the catalytic hydrogen evolution signal was markedly affected by the temperature of the analysed solution and by the concentration of $\mathrm{Co}\left(\mathrm{NH}_{3}\right)_{6} \mathrm{Cl}_{3}$ (depolarizer). The dependence of this signal height on the temperature indicates that it is not a diffusion, but an adsorption controlled reaction. ${ }^{[13]}$ The concentration range of the unknown analyte isolated from the biological material has to be in the range of the calibration curve obtained by using commercially available rabbit liver

(c) $\mathbf{B Y}$ This work is licensed under a Creative Commons Attribution 4.0 International License. 
MT as a calibrant. ${ }^{[12,13]}$ This MT calibration is linear in a very narrow and low range and therefore, biological samples containing MTs usually have to be diluted prior to the analysis.

The duration of the measurement of a single sample was quite time-consuming using the previously defined measurement parameters ${ }^{[13]}$ for the modified Brdička procedure. Since the duration of an analytical measurement is especially important when applied as a routine in biomonitoring studies which require analyses of numerous samples, we modified the duration of one step potential and consequently the scan rate to stipulate if the measurement procedure would still be reliable but faster. Hence, our main goals were: 1) to compare MT levels in fish tissues determined by differential pulse voltammetry (DPV) using two sets of different measurement parameters and 2) to evaluate the application of the faster modified Brdička reaction as a sensitive electrochemical method in biomonitoring studies of metal exposure.

\section{EXPERIMENTAL}

\section{Sampling Procedure}

Fish sampling was performed by electro fishing, according to the Croatian standard HRN EN 14011. ${ }^{[14]}$ European chub (Squalius cephalus Linnaeus, 1758) were sampled in lowland Sava River and 6 specimens were used for MT analysis, while brown trout (Salmo trutta Linnaeus, 1758) were sampled in the karst Krka River in Croatia and 4 specimens were used for MT analysis. Captured fish were kept alive in an opaque plastic tank with aerated river water until further processing in the laboratory. Individual fish were anesthetized with tricaine methane sulphonate (MS 222, Sigma Aldrich, USA) and sacrificed. Liver, gills and the intestine were dissected, weighed and stored at $-80^{\circ} \mathrm{C}$ until further analyses.

\section{Homogenization and Preparation of Cytosolic Fractions of Fish Liver, Gills and Intestine}

Samples of the fish tissues were cut in small pieces and diluted 6 times with cooled homogenization buffer. The homogenizing buffer used for liver and gills homogenization contained 100 mM Tris-HCl/base (Merck, Germany, pH 8.1 at $4{ }^{\circ} \mathrm{C}$ ) supplemented with $1 \mathrm{mM}$ DTT (Sigma, USA) as a reducing agent. Intestinal tissues were homogenized in homogenizing buffer containing $100 \mathrm{mM}$ Tris- $\mathrm{HCl} /$ base (Merck, Germany, pH 8.1 at $4^{\circ} \mathrm{C}$ ) supplemented with $1 \mathrm{mM}$ DTT (Sigma, USA) as a reducing agent, $0.5 \mathrm{mM}$ PMSF (Sigma, USA) and $0.006 \mathrm{mM}$ leupeptin (Sigma, USA) as protease inhibitors. Fish tissues were homogenized by 10 strokes of Potter-Elvehjem homogenizer (Glas-Col, USA) in an ice cooled tube at $6000 \mathrm{rpm}$. Obtained homogenates were centrifuged in the Avanti J-E centrifuge (Beckman Coulter, USA) at $50,000 \times g$ for $2 \mathrm{~h}$ at $4{ }^{\circ} \mathrm{C}$. Resulting supernatants (S50), representing the water soluble tissue fractions (cytosol) were separated and stored at $-80{ }^{\circ} \mathrm{C}$ for subsequent analyses.

\section{Heat-Treatment of the Cytosolic Fractions}

Heat-treatment denatures high molecular mass cytosolic proteins, which would otherwise interfere with the electrochemical MT determination. ${ }^{[15]}$ The cytosolic S50 fractions were 10 times diluted with $0.9 \% \mathrm{NaCl}$ (Suprapur, Merck) and then heat-treated at $85{ }^{\circ} \mathrm{C}$ for $10 \mathrm{~min}$ in the Dri Block (Techne, UK). This dilution of $\mathrm{S} 50$ fraction with $\mathrm{NaCl}$ brings two benefits for analytical determination of MT - it reduces MT co-precipitation with high molecular weight proteins and renders a further sample dilution before the electrochemical analysis almost unnecessary. ${ }^{[15]}$ Afterwards, samples were placed on ice for $30 \mathrm{~min}$ at $4{ }^{\circ} \mathrm{C}$ and then centrifuged at $10,000 \times \mathrm{g}$ for $15 \mathrm{~min}$ at $4{ }^{\circ} \mathrm{C}$ to allow the coagulated proteins to precipitate in Biofuge Fresco centrifuge (Kendro, USA) to obtain MT rich fraction. The resulting heat treated supernatant (HT S50) was stored at $-80{ }^{\circ} \mathrm{C}$ until further analyses.

\section{Determination of MT Concentrations}

MT concentrations were measured in HT S50 by DPV following the modified Brdička procedure. ${ }^{[12,13]}$ Analyses were performed on 797 VA Computrace (Metrohm, Switzerland) with a three-electrode system (hanging mercury drop electrode, $\mathrm{HMDE}$, as a working electrode; an $\mathrm{Ag} / \mathrm{AgCl} /$ saturated $\mathrm{KCl}$ reference electrode; a platinum counter electrode). Measurements were done in $10 \mathrm{~mL}$ of electrolyte solution containing $5 \mathrm{~mL}$ of $2 \mathrm{M} \mathrm{NH} \mathrm{Cl}_{4} / \mathrm{NH}_{4} \mathrm{OH}$ and $5 \mathrm{~mL}$ of $1.2 \times 10^{-3} \mathrm{M} \mathrm{Co}$ $\left(\mathrm{NH}_{3}\right)_{6} \mathrm{Cl}_{3}, \mathrm{pH} 9.5$ which was thermostated to $20{ }^{\circ} \mathrm{C}$ and purged with the pure nitrogen. Measurement parameters for DPV are presented in Table 1. MT concentrations were derived from the calibration straight line, constructed by using the commercially available standard rabbit liver MT2 (Enzo Life Sciences, USA). Standard MT-2 stock solution was prepared by dissolving $1 \mathrm{~g}$ of lyophilised powder in $1 \mathrm{~mL}$ of $0.25 \mathrm{M} \mathrm{NaCl}$. Aliquot of $20 \mu \mathrm{L}$ of $1 \mathrm{mg} \mathrm{mL}^{-1}$ stock solution was further diluted in $1000 \mu \mathrm{L}$ of $\mathrm{H}_{2} \mathrm{O}$ to obtain $19.6 \mu \mathrm{g} \mathrm{mL}-1$ standard MT-2 working solution.

\section{Calculations and Statistical Analyses}

Basic calculations were performed using Microsoft Office Excel 2007, while statistical analyses were performed using SigmaPlot 11.0 (Systat Software, USA). Correlation between two parameter settings applied for the MT measurement in fish tissues was calculated by Pearson correlation coefficient, and coefficient of determination was calculated 
Table 1. The instrumental measuring conditions set on 797 VA Computrace for the MT determination by DPV following the modified Brdička procedure.

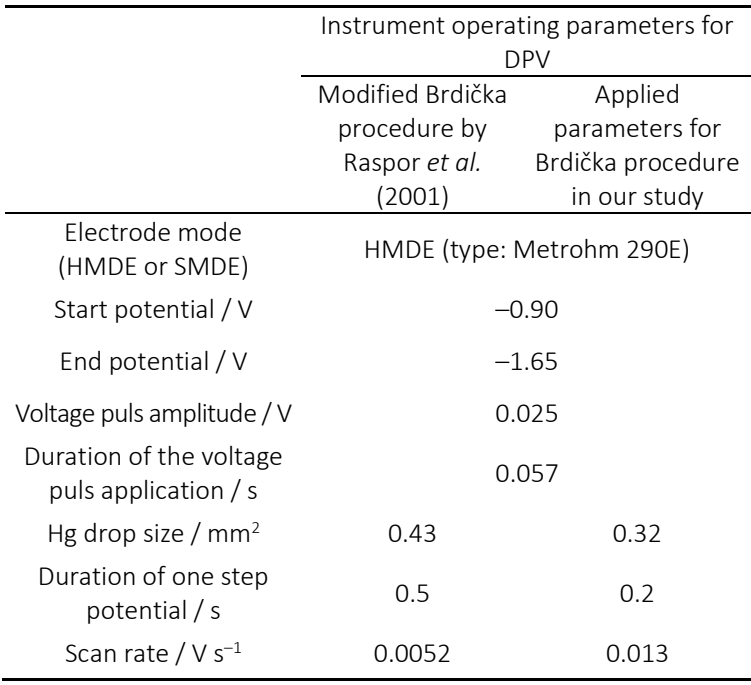

as $\mathrm{R}^{2}$. Variability in MT concentrations of one sample measured by two parameter settings was calculated as the ratio of values obtained by two methods and expressed as percentage. Measurement accuracy for both methods was calculated in a following way: $\left(c_{\text {MTaverage }}-c_{\text {MTstd }}\right) / c_{\text {MTstd }} \times 100$; precision was expressed as the relative standard deviation (RSD) and calculated in a following way: SD / $C_{\text {MTaverage }} \times 100$; and recovery (or trueness) was calculated as $c_{\text {MTaverage / }}$ $c_{\mathrm{MTstd}} \times 100$.

\section{RESULTS AND DISCUSSION}

\section{Calibration Curves}

Calibration curves were constructed using MT-2 rabbit liver standard for both parameter settings, previously used and explained by Raspor et al. ${ }^{[13]}$ and novel with the modified instrumental measuring conditions applied in this study. Linear calibration curves were obtained by four additions of standard MT-2 working solution $\left(\gamma_{\mathrm{MT}}=19.6 \mu \mathrm{g} \mathrm{mL}^{-1}\right)$ : $1^{\text {st }}$ addition - concentration in the cell was $0.04 \mu \mathrm{g} \mathrm{mL}^{-1}, 2^{\text {nd }}$ addition - concentration in the cell was $0.08 \mu \mathrm{g} \mathrm{mL}-1,3^{\text {rd }}$ addition - concentration in the cell was $0.12 \mu \mathrm{g} \mathrm{mL}^{-1}$ and $4^{\text {th }}$ addition - concentration in the cell was $0.16 \mu \mathrm{g} \mathrm{mL}^{-1}$. Four voltammograms were recorded for each addition of standard MT-2 working solution and the mean value of the MT peak current at these 4 voltammograms represented one point of the calibration line (Figures 1, 2). Voltammograms obtained by the addition of MT-2 standard in several steps represented the characteristic responses for the mechanism of the modified Brdička reaction explained in detail by Raspor. ${ }^{[12]}$ In brief, first reduction signal is observed at peak potential $E_{\mathrm{p}}=-1.28 \mathrm{~V}$ and it represents the reduction of Co(III) complex to Co(II). [12] If MTs are present, there is a reaction between the $\mathrm{SH}$-groups of the proteins and $\mathrm{Co}$ (II) complex and the reduction of this $\mathrm{RS}_{2} \mathrm{Co}$ complex can be seen at $E_{\mathrm{p}}=1.35 \mathrm{~V} .{ }^{[12]}$ The protons liberated in this reaction get reduced at $E_{\mathrm{p}}=-1.48 \mathrm{~V}$ and this step represent the catalytic hydrogen wave which is proportional to the MTs concentrations and used for the construction of the calibration curve and MTs quantification ${ }^{[12]}$ (Figures 1,2 ). It is clearly seen that with the addition of larger amounts of MTs, the peak of $\mathrm{Co}$ (II) at $E_{\mathrm{p}}=-1.28 \mathrm{~V}$ decreases because of the formation of protein complex with $\mathrm{MT}$, while the peak of the $\mathrm{RS}_{2} \mathrm{Co}$ complex and MT peak increase proportionally to the MT additions ${ }^{[12]}$ (Figures 1, 2).

Obtained voltammograms and linear calibration curves are shown in Figure 1 (duration of one step potential of $0.5 \mathrm{~s}$ and scan rate $0.0052 \mathrm{~V} \mathrm{~s}^{-1}$ ) and Figure 2 (duration of one step potential of $0.2 \mathrm{~s}$ and scan rate $\left.0.013 \mathrm{~V} \mathrm{~s}^{-1}\right)$. The obtained slopes of the calibration straight lines were repeatable and for the operating parameters used in the modified Brdička procedure by Raspor et al. ${ }^{[13]}$ (duration of one step potential of $0.5 \mathrm{~s}$ ), the slope was $-5.353 \times 10^{-4}$, while the slope obtained with new operating parameters (duration of one step potential of $0.2 \mathrm{~s}$ ) was $-3.658 \times 10^{-4}$. In order to evaluate measurement accuracy and precision, $19.6 \mu \mathrm{g} \mathrm{mL}^{-1}$ MT-2 rabbit liver standard was added as a sample in the electrolyte solution and its concentration was measured repeatedly twelve times and compared by both methods. For applied parameter settings using $0.0052 \mathrm{~V} \mathrm{~s}^{-1}$ and $0.013 \mathrm{~V} \mathrm{~s}^{-1}$ as a scan rate accuracy was $-0.12 \%$ and $-2.0 \%$, RSD was $1.89 \%$ and $1.93 \%$, while recovery was $99.8 \%$ and $98.0 \%$, respectively (Table 2 ). Therefore, both measurement conditions meet the acceptance criteria set for precision and accuracy $(<10 \%)$, so presented novel parameter setting of the modified Brdička procedure has high potential to be applied in the biomonitoring studies. The main advantage of the lower scan rate applied in a new instrumental setting is faster measurement procedure for the MT quantification in biological samples, giving the increase in the sample throughput.

\section{Fish Samples}

Both DPV parameter settings (scan rate $0.0052 \mathrm{~V} \mathrm{~s}^{-1}$ and $0.013 \mathrm{~V} \mathrm{~s}^{-1}$ ) were applied for the measurement of unknown MT concentrations in biological samples, i.e. fish liver, gills and the intestine. In the biomonitoring studies several fish organs such as gills, liver and intestine are often used as target bioindicator organs and MT levels measured in cell cytosols represent an early warning sign of metal exposure in the environment. ${ }^{[16-20]}$ In the present study, MT levels in biological samples, hepatic HT S50 of European chub and brown trout and gills and the intestine of European chub were measured by both parameter settings with the aim to 
compare the obtained MT concentrations and evaluate the application of Brdička reaction with the novel operating parameters. As the method of differential pulse voltammetry (DPV) is generally very sensitive and the linearity range is narrow, optimal conditions need to be used ${ }^{[12]}$ and measured values in the unknown samples have to be in the range of the determined calibration curves, preferably around the central part of the linear calibration where the confidence intervals are the narrowest. If measured sample concentrations are not in the calibration range, then sample volume or concentration have to be adjusted by addition of appropriate sample volume to the electrolyte solution, or by appropriate sample dilution, respectively.

Since the preparation steps of HT S50 fraction for MT measurement involved 60 times dilution of the initial fish tissue, there was no need to additionally dilute HT S50 of fish tissues prior to the measurement by both DPV parameter settings if sample aliquots of 20-40 $\mu \mathrm{L}$ were added to the electrolyte solution of $10 \mathrm{~mL}$. Measurements of fish samples showed that there were no significant differences in MT levels in fish tissues obtained by the two different parameter settings (Table 3 ). Coefficient of determination $\left(R^{2}\right)$ between two measurements of different scan rates for all analysed fish tissues was 0.94 , pointing to high correlation between them. The variability in MT concentrations was $0.3-22 \%$ when the concentrations of the same fish tissues measured by two parameter settings were compared.

\section{Application and the Sensitivity of the Modified Brdička Reaction}

Modified Brdička reaction is a commonly used electrochemical method for MT determination in different biological samples. ${ }^{[4,21-23]}$ Development of electrochemical
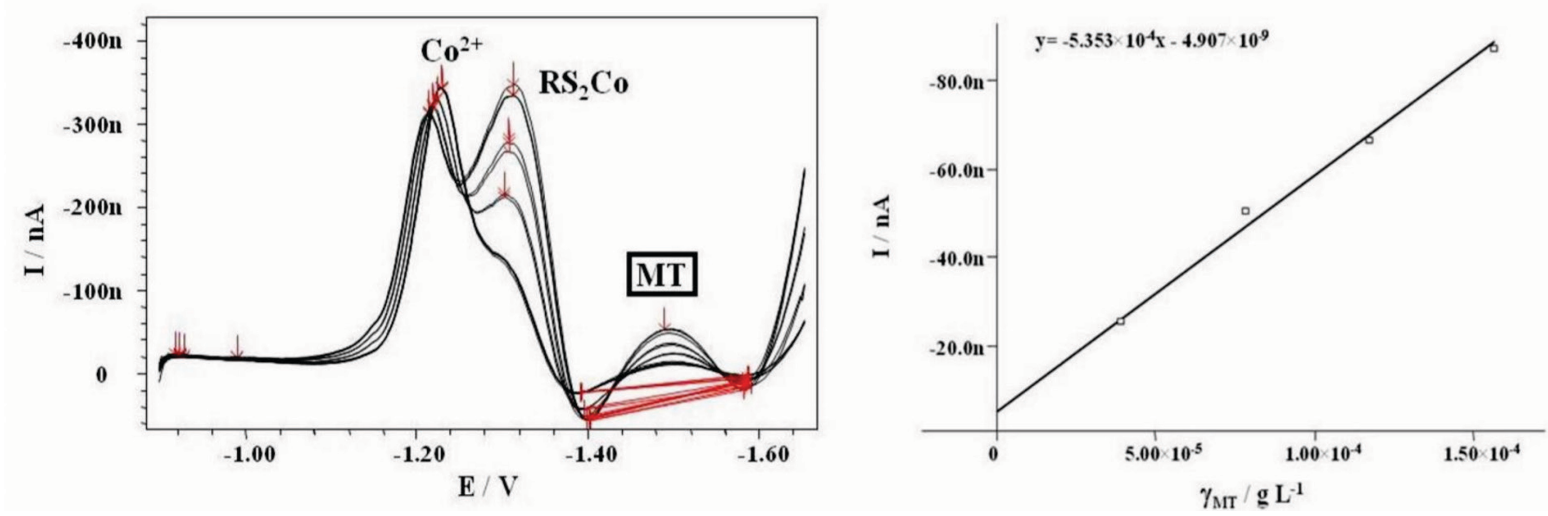

Figure 1. Voltammograms and calibration curve obtained by the four additions of MT-2 standard as a calibrant and using the modified Brdička reaction by Raspor et al. [12]. Used step time is $0.5 \mathrm{~s}$, and scan rate is $0.0052 \mathrm{~V} \mathrm{~s}^{-1}$. The slope of the straight line was $-5.353 \times 10^{-4}$.
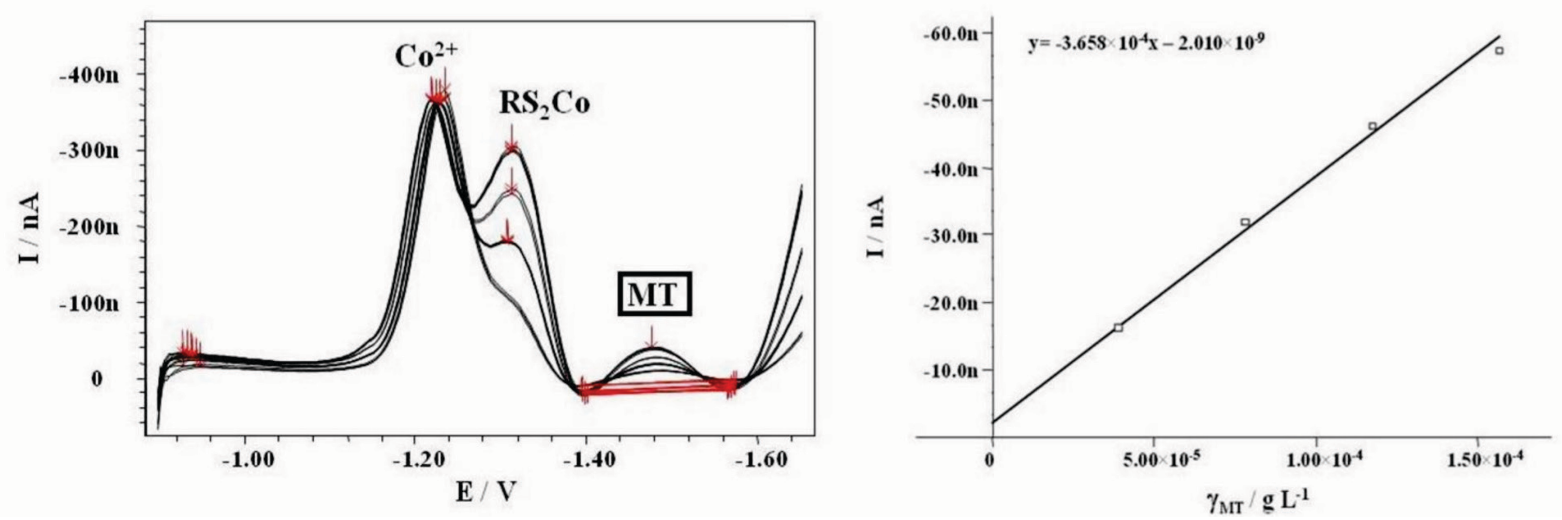

Figure 2. Voltammograms and calibration curve obtained by the four additions of MT-2 standard as a calibrant and using the new modified Brdička reaction. Used step time is $0.2 \mathrm{~s}$, and scan rate is $0.013 \mathrm{~V} \mathrm{~s}^{-1}$. The slope of the straight line was $-3.658 \times 10^{-4}$. 
Table 2. Accuracy and precision of the applied Brdička procedures (scan rate $0.0052 \mathrm{~V} \mathrm{~s}^{-1}$ and $0.013 \mathrm{~V} \mathrm{~s}^{-1}$ ) based on 12 repeated measurements of standard rabbit liver MT-2 concentration.

\begin{tabular}{|c|c|c|}
\hline & Scan rate $0.0052 \mathrm{~V} \mathrm{~s}^{-1}$ & Scan rate $0.013 \mathrm{~V} \mathrm{~s}^{-1}$ \\
\hline & \multicolumn{2}{|c|}{ True concentration / $\mu \mathrm{g} \mathrm{mL^{-1 }}$} \\
\hline & \multicolumn{2}{|c|}{19.6} \\
\hline & \multicolumn{2}{|c|}{ Measured concentration / $\mu \mathrm{g} \mathrm{mL^{-1 }}$} \\
\hline & 19.883 & 18.703 \\
\hline & 19.554 & 19.570 \\
\hline & 18.700 & 18.776 \\
\hline & 19.888 & 19.628 \\
\hline & 19.299 & 19.117 \\
\hline \multirow{7}{*}{ MT-2 standard } & 19.788 & 19.346 \\
\hline & 19.311 & 18.794 \\
\hline & 19.330 & 19.632 \\
\hline & 19.931 & 19.676 \\
\hline & 19.718 & 19.196 \\
\hline & 19.980 & 18.784 \\
\hline & 19.546 & 19.271 \\
\hline Average & 19.56 & 19.21 \\
\hline SD & 0.37 & 0.37 \\
\hline Precision, RSD / \% & 1.89 & 1.93 \\
\hline Accuracy / \% & -0.12 & -2.00 \\
\hline Recovery / \% & 99.8 & 98.0 \\
\hline
\end{tabular}

methods have improved the quantification of analytes with lowering the detection range to as low as $10^{-7}$ do $10^{-10} \mathrm{M} \cdot{ }^{[4,23]}$ In our research, method was confirmed as sensitive, fast and reliable technique for quantification of MTs in tissues of freshwater fishes. The detection limit for MT was evaluated as $3 \mathrm{nM}$. The change in the duration of one step potential and scan rate have not influenced the limit of detection, accuracy and reliability of the measurement results, but contributed to faster measurements and consequently resulted in time-saving modification. MT levels in biological samples were highly comparable when using both parameter settings - modified Brdička reaction by Raspor et al. ${ }^{[13]}$ (scan rate $0.0052 \mathrm{~V} \mathrm{~s}^{-1}$ ) and the new one from this research (scan rate $0.013 \mathrm{~V} \mathrm{~s}^{-1}$ ).

Although there are many methods used for MT quantification ${ }^{[4,5]}$ one of the main advantages of the DPV and Brdička procedure is that they require a small amount of the samples to conduct the assay. This is especially useful when small animals or small tissues (e.g. crustaceans, bivalves, fish tissues) are applied as bioindicators, what is
Table 3. Comparison of MTs concentrations measured in liver, gills and the intestine of European chub (Squalius cephalus Linneaus, 1758) and in the liver of brown trout (Salmo trutta Linnaeus, 1758) by modified Brdička procedure by Raspor et al. (2001) (scan rate: $0.0052 \mathrm{~V} \mathrm{~s}^{-1}$ ) and faster modified Brdička reaction from our study (scan rate: $0.013 \mathrm{~V} \mathrm{~s}^{-1}$ ).

\begin{tabular}{|c|c|c|}
\hline \multirow{2}{*}{ Fish tissues } & \multicolumn{2}{|c|}{ MT determination / $\mu \mathrm{g} \mathrm{mL^{-1 }}$} \\
\hline & Scan rate $0.0052 \mathrm{~V} \mathrm{~s}^{-1}$ & Scan rate $0.013 \mathrm{~V} \mathrm{~s}^{-1}$ \\
\hline \multicolumn{3}{|c|}{ European chub (Squalius cephalus Linnaeus, 1758) } \\
\hline Liver1 & 23.70 & 24.08 \\
\hline Liver2 & 23.08 & 18.95 \\
\hline Liver3 & 24.34 & 21.83 \\
\hline Liver4 & 28.28 & 33.61 \\
\hline Liver5 & 20.37 & 19.36 \\
\hline Gills1 & 25.45 & 26.32 \\
\hline Gills2 & 25.14 & 29.24 \\
\hline Gills3 & 22.67 & 22.75 \\
\hline Gills4 & 23.89 & 25.86 \\
\hline Intestine1 & 37.21 & 43.10 \\
\hline Intestine2 & 32.38 & 32.84 \\
\hline Intestine3 & 36.76 & 41.97 \\
\hline Intestine4 & 42.80 & 43.30 \\
\hline Intestine5 & 44.57 & 45.44 \\
\hline Intestine6 & 53.23 & 52.57 \\
\hline \multicolumn{3}{|c|}{ Brown trout (Salmo trutta Linnaeus, 1758) } \\
\hline Liver1 & 23.43 & 23.64 \\
\hline Liver2 & 23.33 & 24.13 \\
\hline Liver3 & 35.18 & 35.31 \\
\hline Liver4 & 21.52 & 19.33 \\
\hline
\end{tabular}

often the case in the biomonitoring studies in aquatic ecosystems. On the other hand, one of the main disadvantages of the previously used procedure was that the method was time-consuming, but presented research showed that this problem can be overcome by decreasing the duration of one step potential from $0.5 \mathrm{~s}$ to $0.2 \mathrm{~s}$. As a result of this change, the scan rate is faster and allows the application of Brdička reaction in MT measurement in biomonitoring studies, in which many samples of bioindicator organisms have to be analysed.

\section{CONCLUSIONS}

Improvement of the modified Brdička reaction, which is commonly used electrochemical method for the MT 
measurement, included the change in two measurement parameters, duration of one step potential was lowered from $0.5 \mathrm{~s}$ to $0.2 \mathrm{~s}$, and scan rate was consequently increased from $0.0052 \mathrm{~V} \mathrm{~s}^{-1}$ to $0.013 \mathrm{~V} \mathrm{~s}^{-1}$. Both applied parameter settings meet the acceptance criteria set for accuracy and precision, i.e. accuracy was $-0.12 \%$ and $-2.00 \%$, RSD was $1.89 \%$ and $1.93 \%$, while recovery was $99.8 \%$ and $98.0 \%$. Coefficient of determination $\left(R^{2}\right)$ between two parameter settings applied for the MT measurement in different fish tissues was 0.94. Therefore, presented changes in the duration of one step potential and scan rate did not influence the accuracy and reliability of the results, but had a positive impact on the duration of reaction making the measurement much faster. This improvement will especially be useful and applicable in different biomonitoring studies which require the analyses of numerous biological samples and a high sample throughput, meaning the measurement of more samples in a shorter time.

Acknowledgment. This work was supported by the Croatian Science Foundation, within the project "Accumulation, subcellular mapping and effects of trace metals in aquatic organisms" AQUAMAPMET (IP2014-09-4255). The authors are also grateful for valuable help in the field work to the members of the Laboratory for Aquaculture and Pathology of Aquatic Organisms from the Division for Marine and Environmental Research at the Ruđer Bošković Institute.

\section{REFERENCES}

[1] P.-E. Olsson, P. Kling, C. Hogstrand in Metal Metabolism in Aquatic Environments, (Eds.: W. J. Langston, M. J. Bebiano), Chapman and Hall, London, 1998, pp. 321-350.

[2] J. C. Amiard, C. Amiard-Triquet, S. Barka, J. Pellerin, P. S. Rainbow, Aquat. Toxicol. 2006, 76, 160.

[3] R. P. Cosson, J. C. Amiard in Use of Biomarkers for Environmental Quality Assessment, (Eds.: L. Lagadic, T. Caquet, J. C. Amiard, F. Ramade), Science Publishers, Enfield, New Hampshire, 2000, pp. 79-111.
[4] M. Ryvolova, S. Krizkova, V. Adam, M. Beklova, L. Trnkova, J. Hubalek, R. Kizek, Curr. Anal. Chem. 2011, 7, 243.

[5] A. Vojtech, I. Fabrik, T. Eckschlager, M. Stiborova, L. Trnkova, R. Kizek, Trends Analyt Chem 2010, 29, 409.

[6] R. Brdička, Coll. Czech. Chem. Commun. 1933, 5, 112.

[7] E. Paleček, Z. Pechan, Anal. Biochem. 1971, 42, 59.

[8] P. F. Kehr, Ph.D. Thesis, Purdue University, West Lafayette, Indiana, 1973, p. 97.

[9] R. W. Olafson, R. G. Sim, Anal. Biochem. 1979, 100, 343.

[10] J. A. Thompson, R. P. Cossont, Mar. Environ. Res. 1984, 11, 137.

[11] P. E. Olsson, C. Haux, Aquat. Toxicol. 1986, 9, 231.

[12] B. Raspor, J. Electroanal. Chem. 2001, 503, 159.

[13] B. Raspor, M. Paić, M. Erk, Talanta 2001, 55, 109.

[14] HRN EN 14011, 2005. Fish Sampling by Electric Power [Uzorkovanje riba električnom strujom].

[15] M. Erk, D. Ivanković, B. Raspor, J. Pavičić, Talanta 2002, 57, 1211.

[16] A. Hamza-Chaffai, R. P. Cosson, C. Amiard-Triquet, A. El Abed, Comp. Biochem. Physiol., Part C 1995, 111, 329.

[17] V. Filipović, B. Raspor, Water Res. 2003, 37, 3253.

[18] M. Podrug, B. Raspor, Environ. Monit. Assess. 2009, 157, 1.

[19] Z. Dragun, V. Filipović Marijić, D. Kapetanović, D. Valić, I. Vardić Smrzlić, N. Krasnići, Ž. Strižak, B. Kurtović, E. Teskeredžić, B. Raspor, Environ. Sci. Pollut. Res. 2013, 20, 4954.

[20] M. Sevcikova, H. Modra, K. Kruzikova, O. Zitka, D. Hynek, A. Vojtech, O. Celechovska, Z. Svobodova, Int. J. Electrochem. Sci. 2013, 8, 1650.

[21] Z. Dragun, M. Podrug, B. Raspor, Comp. Biochem. Physiol., Part C 2009, 2, 209.

[22] V. Filipović Marijić, Z. Dragun, M. Sertić Perić, R. Matoničkin Kepčija, V. Gulin, M. Velki, S. Ečimović, B. K. Hackenberger, M. Erk, Chemosphere 2016, 154, 300.

[23] I. Fabrik, Z. Ruferova, K. Hilscherova, V. Adam, L. Trnkova, R. Kizek, Sensors 2008, 8, 4081. 